\title{
Learning and Doing Participatory Rural Appraisal During the Covid-19 Pandemic in Empowering Communities
}

\author{
Riya Fajar Wati", Eka Putri, Nur Rahmatul Chasanah, Harto Wicaksono, Asma \\ Luthfi
}

Department Sociology and Anthropology, Universitas Negeri Semarang

*Corresponding author. Email: riyafajar2@gmail.com

\begin{abstract}
.
The stipulation of the covid-19 virus as a global pandemic has resulted in massive changes in all aspects of life for the world community. The increasing number of cases of covid-19 transmission accompanied by an increasingly significant number of deaths has an impact on the imposition of social distancing or physical distancing in a number of countries. This has led to changes in the order of life of the Indonesian people, especially the socio-economic conditions of the Indonesian people which have experienced a lot of decline, so that it requires efforts to empower them. PRA (Participatory Rural Appraisal) is an approach to community empowerment that involves active community participation. It's just that, during the Covid-19 Pandemic, PRA experienced problems in its implementation because of the physical distancing policy. Therefore, this paper will explain the actualization of PRA during the Covid-19 pandemic. This paper originates from a qualitative research conducted in Karanglo Village, Klaten Regency, Central Java. The method of data collection is done by using the method of observation, interviews, and document studies using data triangulation techniques as a method of data validity. This research focuses on: (1) Implementation of the PRA approach in the empowerment process of the Karanglo village community during the Covid-19 pandemic, (2) The results of the identification of problems and potentials of the Karanglo village community originating from the PRA process carried out, (3) Opportunities and challenges of implementing PRA during the Covid-19 pandemic.
\end{abstract}

Keywords: Covid-19, Doing, Empowering Communities, Learning, Participatory Rural Appraisal

\section{INTRODUCTION}

Covid-19 is a new type of disease that has caused changes in the world's life order in early 2020. The virus, which was discovered in 2019 in Wuhan, China, has even spread widely in almost all countries in the world. According to WHO data at the beginning of the spread of Covid-19, precisely in March 2020, there were 65 countries in the world that had been exposed to Covid-19 (Yuliana, 2020). Even the WHO has designated Covid-19 as a world pandemic. Indonesia is one of the countries in the world exposed to the Covid19 virus, this condition began after President Joko Widodo confirmed that there were 2 Indonesian citizens (Indonesian citizens) who were exposed to Covid-19 to be precise on March 2, 2020. After this confirmation the Covid-19 case increased which is very significant, this condition forces the government to implement various policies as an effort to deal with the Covid-19 case. Central Java is one of the regions in Indonesia that has the most positive cases of corona in Indonesia, even since the Covid-19 pandemic hit Indonesia there have been 32,738 confirmed positive cases of Covid-19 in Central Java and even accompanied by an increase in positive cases which continues to increase.

Seeing the large number of cases of Covid-19 exposure that has hit the world, including in Indonesia, has caused changes in the pattern of people's lives in almost all sectors of life and forces all people to be able to adapt to these conditions. However, in the adaptation process the negative impacts due to Covid-19 are clearly felt. One of them is the economic downturn, this is due to restrictions that cause the global economic process to 
experience paralysis and even paralysis of economic activity due to Covid-19 is one of the major threats to the world. According to Kusno (2020) in his research, there are many opinions that state that the outbreak of Covid-19 will be the end of the global economy. Furthermore, the impact of activity restrictions in Indonesia is also the cause of economic loss, according to research Hadiwardoyo (2020) which states that activity restrictions due to the Covid-19 pandemic have caused economic losses nationally. In fact, according to the Head of National Development Planning Agency of Indonesia (BAPPENAS), the economic crisis that hit Indonesia due to the Covid-19 pandemic could make Indonesia's economy minus $1.1 \%$ in 2020 (Laucereno, 2020).

Therefore, various solutions need to be implemented especially to care for the Indonesian economy, one of which is community empowerment. This empowerment is expected to be able to help improve the economy, especially amid the imposed restrictions. PRA (participatory rural appraisal) is an empowerment-based approach that can be used as an approach method in society. In the research Ridwan et al. (2019), states that the PRA (participatory rural appraisal) method is an approach method that puts forward the results of the formulation together according to the needs of the community. In this case, of course, it requires active participation from the community. Public Participation according to Government Regulation Number 45 of 2017 ( in Grediani, 2020), in the general provisions of article (1), Community Participation is the role of the Community to channel their aspirations, thoughts and interests in the implementation of regional government. Meanwhile, the community is an individual Indonesian citizen, community group, and community organization.

However, the use of the PRA (participatory rural appraisal) method in overcoming social problems in society during the Covid-19 pandemic received less attention. Departing from this, the researcher is interested in conducting research with a research focus on empowerment based on the application of the PRA (participatory rural appraisal) empowerment method as a solution to community development during the Covid19 period.

\section{RESEARCH METHOD}

The research method used in this research is a qualitative research method with the Participatory Rural Appresial (PRA) approach. PRA is a research method developed to increase community participation in development (Hudayana et al., 2019). Through PRA, the community is not only an object that accepts development but also becomes a subject that actively participates in the planning, actuating. and evaluating of development programs. This research originated from a qualitative research conducted in Karanglo Village,
Klaten Regency, Central Java. The focus of the research is on the actualization of PRA during the Covid-19 pandemic. Karanglo Village was chosen as the research location because in Karanglo Village there is a Covid19 virus prevention program which is carried out by implementing the principles of Participatory Rural Appreciation (PRA). Data collection techniques are carried out by observation, interviews, and document studies to obtain main and supporting data sources. Data obtained by conducting interviews with informants, namely the head of the RT, the head of the youth organization, and the residents of Karanglo Village. The validity of the data in this study used triangulation techniques by comparing the results of observations and interviews that had been conducted. Data analysis techniques consist of data collection, data reduction, data presentation, and decision making or verification.

\section{DISCUSSION}

\subsection{Karanglo Community during the Covid- 19.}

Karanglo Village is located in South Klaten District, Klaten Regency, Central Java. This village consists of 2 RT and 2 RW with an area topography surrounded by rice fields so that the majority of the community's livelihoods are farmers. Apart from being farmers, the people of Karanglo Village also work as traders, laborers, private employees, and civil servants. Therefore, the people of Karanglo Village have heterogeneity in socioeconomic status. Even so, the people of Karanglo Village still maintain the value of mutual cooperation and harmony among residents regardless of socio-economic status. The location of the village which is not far from the city center makes it easier for residents to access socio-economic activities. The development in Karanglo Village is also not far behind with other villages as seen from the existence of public facilities such as mosques, children's playgrounds, volleyball parks, and so on.

With the stipulation of the covid-19 virus as a global pandemic, it has resulted in changes in all aspects of people's lives. Social restrictions, quarantine, closure of most jobs have an impact on society. As a global disaster, the Covid-19 pandemic has inspired changes in social behavior including social solidarity (Herlan et al., 2020).

Changes due to the Covid-19 pandemic have also occurred in Karanglo Village. Many villagers were sent home during the Covid-19 pandemic, which resulted in their economic conditions getting worse. Not only that, the Covid-19 pandemic which requires people to work at home has resulted in changes to the social life of the community which is now based on social media. During the pandemic, the government and the community helped each other to prevent the spread of the Covid-19 
virus. This is also done by the people of Karanglo Village through the Covid-19 virus prevention program which is carried out by implementing the principles of Participatory Rural Appreciation (PRA).

This program is expected to help prevent the spread of the Covid-19 virus from spreading. This program is carried out by involving direct participation so that villagers are not only objects but also the subject of the Covid-19 prevention program. Even though there are social restrictions, the implementation of the Covid-19 prevention program is still carried out by observing health protocols. Therefore, the Covid-19 prevention program in Karanglo Village is interesting to study because in the implementation of the program there is an actualization of PRA. The program includes PRA implementation, community involvement in program implementation, as well as obstacles and challenges experienced by the community.

\subsection{Implementation of the PRA approach in the Karanglo Village Community Empowerment Process during the Covid-19 Pandemic}

The implementation of community empowerment in Karanglo Village to prevent the spread of Covid-19 was carried out through "My Real Action Against Covid19". This program is carried out by implementing the PRA approach through four stages, namely problem identification, program planning, program implementation and evaluation of program implementation. In the activity of identifying problems and potentials of the community, it is carried out by forming an identification group or group. The formation of the group was carried out by utilizing mass media with the community to take real action to prevent Covid-19. Through the Whatsapp group, some information can be obtained about the development of Covid-19, prohibitions and warnings to avoid Covid-19, as well as various planned activities that will be carried out to prevent the spread of Covid-19 to the public. This activity shows the principle of PRA by involving the community to learn from each other and share experiences. The groups that have been formed are also used as media for open and informal discussions in accordance with PRA principles.

From the problem identification process, several problems can be formulated to determine the program of activities in "My Real Action Against Covid-19." These problems include economic problems, limited social interaction between residents, and an increase in public concern and anxiety as a result of the spread of the Covid-19 virus. The process of formulating the covid-19 prevention action program was also carried out by online discussions through the WhatsApp group. Discussion activities were carried out by deliberating together to determine steps to prevent Covid-19. This is done by taking into account the principles of PRA.

From the formulation of these problems, several program activities were compiled "My Real Action Against Covid-19." The first program is to conduct socialization and outreach to the public about healthy living by providing information about the procedures and behavior of healthy living as a measure to prevent the Covid-19 virus online via WhatsApp or Instagram. Then, the program provides disinfectant fluids to the public to prevent the spread of the Covid-19 virus. The last program is to spray disinfectants throughout the community. In its implementation, the community is directly involved at every stage of the activity so that there is an implementation of the PRA approach principles in the program. Therefore, the implementation of "My Real Action Against Covid-19" is a campaign step to prevent the spread of the Covid-19 virus for the community.

\subsection{Identification of Problems and Potentials of the Karanglo Village Community from the PRA Process}

There are several problem identifications underlying the social conditions of the people of Karanglo Village during the Covid-19 pandemic, the following are the results of the identification: Firstly, economy problem. Economic problems are the main problems faced by the people of Karanglo Village. This is because the majority of people work as laborers who earn daily income. With the Covid-19 pandemic, it has had an impact on decreasing the opinion of the local community, so that it becomes difficult for people to make a living. The main factor behind this condition is the establishment of restrictions after the outbreak of the Covid-19 pandemic. In addition, some residents who work in the trade sector also complained about a decrease in income turnover. From these conditions, the Covid-19 pandemic has made it even more difficult for the local community's economy.

Secondly, Limited social interaction between residents. Limited social interaction between residents is also a problem faced by residents. Residents have difficulty interacting as usual. Even among mothers, all activities including PKK, toddler health services, Healthy Gymnastics, and all activities requiring gathering have been stopped temporarily as a measure to anticipate the spread of corona. Youths like Youth Organization are also affected by the impact they are prohibited from simply hanging out or hanging out together. The presence of the corona virus has resulted in all citizen activities related to social activities being hampered and even temporarily delayed. Even so, the residents' daily activities are still running as usual. For example, farmers still go to the rice fields, children 
continue to play around their home environment, and women are often seen chatting in front of the house.

Thirdly, Increased worry and anxiety of the people of Karanglo Village. This corona virus also causes people to feel worried about health and life safety. With the outbreak of this virus, people are becoming more careful in interacting with other people. Even residents who still have to work outside use personal protective equipment such as masks and wear antiseptics. This was done to avoid the spread of the corona virus to Karanglo Village. This increased level of anxiety has also prevented local people from carrying out daily activities.

The identification of the above problems was obtained from a deliberation process for local residents using the WhatsApp media. This action is driven by the desire of local residents to jointly overcome the problems faced in the Covid-19 pandemic. Through this media, the community intensively shares information, experiences and suggestions in order to create real action as real action to respond to the problems faced by villagers. From this awareness, the people of Karanglo Village have the potential to use the PRA method as an approach to empowering local communities. This is because in the discussion process the community has used the principle of empowerment by using PRA.

In the discussion process, the community carried out in a relaxed and informal manner so that people could exchange information and experiences related to the spread of the Covid-19 virus. From the discussion, several questions were asked as a reference for members of the discussion to have an opinion. As a facilitator as well as a moderator in the discussion, he tries to encourage all group members to identify the problems and potentials of the people of Karanglo Village. In carrying out the discussion, members are required to identify in advance so that the issues discussed do not go beyond the context of the Covid-19 pandemic. For starters, there were questions about the opinions of residents regarding the problems that were felt due to the impact of the corona virus. In order to regulate this discussion, there is a moderator who is in charge of directing the flow of the discussion being carried out.

\subsection{Implementation of the Karanglo Village Community Empowerment Program to Prevent the Spread of Covid-19}

The implementation of "My Real Action Against Covid-19" as a community empowerment program in Karanglo Village was carried out to support the government in order to prevent the spread of the Covid19 virus from spreading. By applying PRA principles in its implementation, the people of Karanglo Village do not participate directly as subjects in the program. The direct involvement of the villagers can be seen in the implementation of the program of spraying disinfectant liquids throughout the environment. The disinfectant spraying activity is carried out regularly every week by involving Youth organization of Karanglo Village. Even though the implementation of the program is carried out directly, the community still follows health protocols by wearing masks and maintaining a distance. Through this routine program, it is hoped that it can help prevent the spread of the Covid-19 virus in Karanglo Village.

PRA or Participatory Rural Appraisal is one of the approaches taken in the implementation of community empowerment. By using the PRA or Participatory Rural Appraisal approach, it is hoped that there will be direct community participation or involvement to solve the problem or problem at hand. In every business there must be opportunities and challenges that accompany it. As is the case in efforts to handle Covid-19 using this PRA approach. According to KBBI, opportunities are spaces, both concrete and abstract, which provide the possibility for an activity to take advantage of it in an effort to achieve its goals. Meanwhile, challenges are things or objects that inspire determination to improve the ability to solve problems, or things or objects that need to be overcome.

In its implementation, PRA is carried out by identifying problems first through discussions carried out using whatsapp group media, to the formulation of activities with the form of activities. Of course, in its implementation it is expected to provide benefits which then become opportunities or prospects as follows: (1) Community involvement makes the community more active and efficient in their village, and can take advantage of its potential in preventing the spread of Covid-19. (2) Increasing cooperation and mutual help (gotong royong) among others for their involvement in preventing the spread of Covid-19. (3) The implementation of PRA can provide an alternative effort in breaking the rope of the spread of Covid-19, so it is hoped that the spread of the virus can be stopped. (4) Assisting the government in voicing outreach related to the prevention of Covid-19.

The challenges that accompany the implementation of PRA are: First, a. A further discussion is needed to coordinate residents in mass spraying of disinfectant liquid, given how difficult it is to coordinate residents to carry out mass spraying activities. Second, There are residents who do not obey curfew regulations and calls for distance, so it is necessary to conduct more in-depth socialization. 


\section{CONCLUSION}

The implementation of PRA or Participatory Rural Appraisal during the Covid-19 pandemic is considered appropriate in order to fight the spread of the Covid-19 virus. The implementation model is carried out by involving direct community participation to identify potentials, formulate problems, implement activities, and evaluate programs. So that the PRA or Participatory Rural Appraisal approach is suitable for the campaign to prevent the spread of the covid-19 virus.

PRA is carried out through online media, namely WhatsApp for planning, formulating, implementing, and evaluating activities. There are several activities in the application of PRA, among others: conducting socialization and outreach to the public regarding healthy living, providing community disinfectants, and spraying disinfectants throughout the community. Several activities that have been carried out show the active involvement of the people of Karanglo Village in mutual cooperation to jointly try to deal with the spread of Covid-19. However, in its implementation there are still problems, such as the difficulty of coordinating residents to carry out mass spraying activities, and there are still residents who do not obey curfew regulations and calls for distance. For this reason, problems encountered in the field are a challenge to be addressed immediately.

\section{REFERENCES}

Grediani, E. (2020). Mengungkap Fenomena Anggaran Perubahan dan Partisipasi Masyarakat Akibat Pandemi. IMANENSI Jurnal Ekonomi, Manajemen, Dan Akuntansi Islam, 5(2), 69-78.

Hadiwardoyo, W. (2020). Kerugian Ekonomi Nasional Akibat Pandemi Covid-19. Journal of Business and Entrepreneurship, 2(2), 83-92. https://doi.org/10.24853/baskara.2.2.83-92

Herlan, Efriani, Sikwan, A., Hasanah, Bayuardi, G., Listiani, E. I., \& Yulianti. (2020). Keterlibatan Akademisi Dalam Menanggulangi Dampak Covid-19 Terhadap Masyarakat Melalui Aksi Berbagi Sembako. JCES (Journal of Character Education Society), 3(2), 267-277.

Hudayana, B., Kutanegara, P. M., Setiadi, Indiyanto, A., Fauzanafi, Z., N., M. D. F., Sushartami, W., \& Yusuf, M. (2019). Participatory Rural Appraisal ( PRA ) untuk Pengembangan Desa Wisata di Pedukuhan Pucung, Desa Wukirsari, Bantul. Bakti Budaya, 2(2), 99-112.

kemdikbud. (n.d.). Peluang dan Tantangan. KBBI. Retrieved October 24, 2020, from https://kbbi.kemdikbud.go.id/
Kusno, F. (2020). Global Political Economy Crisis Impact of Pandemic Covid-19. Anterior Jurnal, 19(2), 114-112.

Laucereno, S. F. (2020). Kepala Bappenas Sebut Ekonomi RI Bisa Minus 1,1\% Tahun Ini. Detikfinance. https://finance.detik.com/berita-ekonomi-bisnis/d5227358/kepala-bappenas-sebut-ekonomi-ri-bisaminus-11-tahun-ini

Ridwan, I., Dollo, A., \& Andriyani, A. (2019). Implementasi Pendekatan Participatory Rural Appraisal pada Program Pelatihan. Journal of Nonformal Education and Community Empowerment, 3(2), 88-94. https://doi.org/10.15294/pls.v3i2.34913

Tim detikcom. (2020a). Corona di Jateng 24 Oktober: 32.738 Positif, 2.431 Meninggal. DetikNews. https://news.detik.com/berita-jawa-tengah/d5227091/corona-di-jateng-24-oktober-32738-positif2431-meninggal

Tim detikcom. (2020b). Kapan Sebenarnya Corona Pertama Kali Masuk RI? DetikNews. https://news.detik.com/berita/d-4991485/kapansebenarnya-corona-pertama-kali-masuk-ri

Yuliana. (2020). Corona virus diseases (Covid -19); Sebuah tinjauan literatur. Wellness and Healthy Magazine, 2(1), 187-192. 